\title{
MODERN CONDITION AND ROLE OF MICROFINANCE ORGANIZATIONS (ON THE EXAMPLE OF GEORGIA)
}

\author{
MEDEA CHELIDZE \\ $\mathrm{PhD}$ in Economics, Associate Professor, \\ Georgian Technical University, Georgia \\ m.chelidze@gtu.ge
}

\section{TAMARI BERIDZE}

PhD, Professor,

Georgian Technical University, Georgia

t.beridze@gtu.ge

\section{BELLA GODERDZISHVILI}

PhD in Economics, As. Professor,

Georgian Technical University, Georgia

b.goderdzishvili@gtu.ge

Abstract. The financial companies have hold an important position in the Georgian financial industry, and for this reason, their regulation is an essential issue, which should continue at least in the same manner.

In the developed countries the non-bank sector plays an important role in the development of financial sector as well as the whole economy, which we cannot say about Georgia, due to the obvious dominance of commercial banks in the country.

The aim of our study is to identify the role of microfinance organizations in the financial system of Georgia, and also to show the current state of this market segment. The article is based on the newest references and rich factual materials. The object of the research is microfinance organizations and the degree of their regulation by the state.

The National Bank of Georgia has a full authority to supervise the work of commercial banks, non-bank deposit institutions, microfinance organizations and other organizations, envisaged by the law. The majority of the institutions with microfinance organization status, registered at the National Bank of Georgia, are consumer finance companies with their content. Their work is absolutely legitimate, however, the issuance of the loans are based not on the customer's finance analysis, but the evaluation of a subject or property, presented for the loan insurance, and the funds are not directed to finance the business, but for the customer's needs.

The financial companies have hold important position in the Georgian financial industry, and for this reason, their regulation is an essential issue, which should continue at least in the same manner.

It is problematic that currently many financial companies, pawnshops, internet-lenders or private individuals that are left beyond regulations. There is no guarantee the customerss rights will be protected when the work of the financial intermediaries is not regulated. Such circumstances create a threat to the spread of predatory lending practices in the market, the victim of which becomes the unaware customer.

The results show that it is important to take more active steps on the part of supervisory organizations to develop the segment of microfinance organizations, so as not to reduce their role and importance in the financial system.

KEYWORDS: MICROFINANCE ORGANIZATION, JOINT STOCK COMPANY, NON-BANK DEPOSIT INSTITUTION, LOW-INCOME CITIZEN, COMMERCIAL BANK.

For citation: Chelidze, M., Beridze, T., Goderdzishvili, B. (2020). Modern Condition and Role of Microfinance Organizations (On the Example of Georgia). Globalization and Business, 10. 252-256 https://doi.org/10.35945/gb.2020.10.033 
The main task of microfinance organizations is to reduce poverty by promoting the development of small and medium businesses, and the goal of the supervision of microfinance organizations is to promote the stable function of the microfinance organizations, well as the whole economy, which we cannot say about Georgia, due to the obvious dominance of commercial banks in the country.

In terms of supervision, the microfinance sector is included in the part of non-bank financial sector. The non-bank financial sector of Georgia is only $5.96 \%$ of the consolidate actives of the whole financial sector, from which the microfinance organizations include $1.8 \%$. In the developed countries the non-bank sector plays an important role in the development of financial sector as well as the whole economy, which we cannot say about Georgia, due to the obvious dominance of commercial banks in the country.

The source of legal regulation of the active microfinance organizations in Georgia is the Law of Georgia "On Microfinance Organizations" (July 18, 2006). As a result of the research, conducted on year 2004 by the Microfinance Center of Eastern and Central Europe, the microfinance sector of Georgia was assessed as one of the developed segments within the Eastern and Central Europe and the former Soviet Union countries, however, this activity was not included in the appropriate legislative environment until 2006, which obstructed the future progress of the microfinance market. In 2006 the National Bank of Georgia was tasked to elaborate the draft law in accordance with the amendments and additions made in the Civil Code of Georgia. While working on the draft law the consultations were held with the Government of Georgia, microfinance sector representatives and international organizations.

In 2003 the concept of a specialized microfinance fund appeared in the Civil Code. In 2003 the concept of a „Specialized Microfinance Fund" appeared in the Civil Code. It was a transitional form between the subsidized microfinance programs, financed by the donors and commercial microfinance sector. Therefore, the oldest microfinance organizations take start from the projects, supported by the donors.

In accordance with the Article 3 of the Law of Georgia „On Microfinance Organizations“, „Microfinance Organization is limited liability or joint stock company, a legal entity based on an organizational-legal form, which on the basis of its statement is registered by the National Bank of Georgia and implements the work, envisaged by this law with the supervision of National Bank of Georgia". The Work of microfinance organization is established in the law. In particular, in accordance with the article 4, the microfinance organization is entitled to implement only the following work: Issuing the microcredits, including, consumer, pawn, mortgage, unsecured, group and other loans (credits) for the legal and natural persons, invest in state and public securities, implementation of money transfers, implementation of insurance agent's function, providing micro-credit counseling services, receiving loans (credits) from resident and nonresident legal and natural persons, ownership of basic capital shares of the legal entities, the total quantity of which shall not exceed the $15 \%$ of the basic capital of this microfinance organization, other financial services and operations, defined by the Georgian legislation, including, micro-leasing, factoring, currency exchange, issuance of promissory, bounds, realization, expiation and other operations connected to them. (Law of Georgia "On Microfinance Organizations", 2006, 1)

The National Bank of Georgia registers the limited liability or joint stock companies, established in accordance with the Georgian legislation, the legal form, the type of work and trademark of which correspond with the requirements, envisaged by Law of Georgia "On Microfinance Organizations" and Law of Georgia "On Entrepreneurs". (Order of the President of the National Bank of Georgia N33/04, 2012, 1)

In accordance with the article 48 of the Organic Law of Georgia "On the National Bank of Georgia“, the National Bank of Georgia has a full authority to supervise the work of commercial banks, non-bank deposit institutions, microfinance organizations and other organizations, envisaged by the law. If the National Bank of Georgia, as a result of examination, determines that the microfinance organization violated the norms, established by the Georgian legislation, NBG is entitled to warn them, charge them with a fine or make a decision to cancel the registration of the microfinance organization. (Organic Law of Georgia „On the National Bank of Georgia“, 2009, 15)

In the Law of Georgia "On Microfinance Organizations", it is defined that the total maximum sum of the micro-credit on one debtor shall not exceed 50000 (fifty thousand) GEL. The amount of interest rate, commission fee and service fee is established by the microfinance organization.

The National Bank registers the microfinance organizations, establishes distinct standards to the candidate companies, their founders and directors. The microfinance organizations regularly report to the NBG, and the supervisory framework is directed to the customers' right protection, prevention of illegal income legalization and terrorism financing. The National Bank does not regulate the microfinance organizations deeply, that is the case of commercial banks. This is dictated by the public interest, so that the deposits of the significant parts of society are placed in the financially healthy institutions. For this reason, unlike the banks, microfinance organizations are prohibited to attract deposits from the populations. According to the practitioners of the microfinance sector, the National Bank of Georgia has a regular and arranged communication with the association of development and support of microfinance organizations of Georgia and the reforms announced with regard to the customers' right protection. (Mosiashvili, 2017, 294)

The association of development and support of microfinance organizations of Georgia was established in August, 2009. The main task of the association is to promote the development and reinforcement of the microfinance sector in Georgia, the protection of microfinance organizations) rights and interests, support of the coordination of their judicial guarantees and work, prepare the proposals for alterations in the active legislation, in order 
to ensure the same tax regulations for the microfinance organizations as it is in the case of commercial banks. (The Georgian Microfinance Association, Charter, 2009, 2-3)

The Georgia Microfinance Association is a non-profit organization. The association acts in accordance with the Georgian legislation, international judicial norms and its regulations. Association is a non-profit legal entity, has an independent balance and accounts in banking institutions. The goals of the Georgian Microfinance Association are: to promote the development and strengthening of the microfinance sector in Georgia; to improve the institutional capacities of the microfinance organizations of Georgia and other members of the association; to support the prestige of mutual trust, microfinance organizations and other members of the association; to promote public awareness and knowledge in microfinances; to protect the rights and interests of microfinance organizations and other members of the Association, promoting their judicial guarantees and work coordination; to establish relations with the international organization, which are interested with the development of the microfinance sector and will assist the members of the Association, as well as the Association financially, with grants and other forms; to establish the relations with auditing companies; to ensure the cooperation with international rating companies; to cooperate with the Governmental structures of Georgia, to ensure the participation of the members of the Association in purposely issuing the credits, allocated for small businesses.

The Georgian Microfinance Association unites 25 organizations with high standards. The Association is fully financed by the membership fees. The United States Agency for International Development (USAID) made a significant contribution for its development. (The Georgian Microfinance Association, 2019)

For January 1, 2019, 67 microfinance organizations were registered in Georgia (51 of them were registered in Tbilisi), for August 1, 2018 - 71, for December 31, 2017 - 75, for July 12, 2017 - 83, and for December 31, 2016 - 81. (National Bank of Georgia, 2019)

The majority of the institutions with microfinance organization status, registered at the National Bank of Georgia, is consumer finance companies with their content. Their work is absolutely legitimate, however, the issuance of the loans are based not on the customer's finance analysis, but the evaluation of a subject or property, presented for the loan insurance, and the funds are not directed to finance the business, but for the customer's needs. In this model of loaning, the economic work analysis of the customer is ignored, which may become the reason for excessive credit cargo creation. Therefore, it is wrong to believe that every microfinance organization is also a microfinance organization with its concept. It is desirable, for the active status to be changed and the similar companies to be called their own name, for example - "Registered Finance Company" and only the small part of them to be granted with the microfinance organization status. The same status can be granted to the commercial banks and credit unions, which protect the principles of liability crediting, are oriented on funding the business, and during the crediting process rely on solvency analysis and not the evaluation of the property.

It must be noted that it is fully possible for the microfinance organizations to issue the consumer loans or carry pawn operations together with business-crediting, however the consumer finance element will be a small part of the credit portfolio of these finance institutes.

Interestingly, the microfinance sector has been the most significant financier of the Agriculture in Georgia for years. With the data of NBG, the microfinance organizations leaded in the loans, issued for the agriculture within the last years. This tendency changed since the Government of Georgia started to subsidize the cheap agro-credit program by the commercial banks.

In accordance with the reports, submitted by the microfinance organizations, with the data of the IV quarter of 2018, 4397 people were employed in the Georgian Microfinance Sector, in the similar period of $2017-4742$ people, in the similar period of 2016 - 5899 people, and in the similar period of 2015 - 4901 people.

In 2016-2018 a light supervisory regime was still preserved. However, at the same time, works continued with regard to the completion of regulatory legislative base and supervisory framework, that somewhat aims to reinforce the norms of regulations.

In accordance with the data of the IV quarter of 2018, the total amount of the assets of the sector with regard to the similar period of previous year, was decreased with 3.55\% and amounted to $1,47 \mathrm{bn}$. GEL. The decrease was made at the expense of obligations, which amounted to 1,04 bn. GEL (decrease 8.07\%).

In accordance with the data of the IV quarter of 2018 the amount of net loans was determined by 1,03 bn. GEL and concluded $70.1 \%$ of total assets. It is noteworthy, that the shared indicator of net loans correlation to the total assets has not changed substantially within the last years (decrease $4.07 \%$ ).

In accordance with the data of the IV quarter of 2017 the amount of net loans was determined by $1,073 \mathrm{bn}$. GEL and concluded $70.5 \%$ of total assets.

In accordance with the data of the IV quarter of 2018, the borrowed funds of microfinance sector was $836 \mathrm{ml}$. GEL. In the similar period of 2017 and 2016 the indicators, accordingly amounted to $849 \mathrm{ml}$. GEL and 1,149 bn. GEL.

In accordance with the data of the IV quarter of 2018, the microfinance organizations in Georgia have lend 1,102 bn. GEL in total, which compiles of 786117 in quantity. It is mainly represented by 4 sectors: consumer loans $-337,1$ $\mathrm{ml}$. GEL (30.6\% of portfolio); collateral credits $-299,9(27.2 \%$ of portfolio); trade and services - 187,2 ml. GEL (17.0\% of portfolio); online loans $-105,3 \mathrm{ml}$. GEL (9.6\% of portfolio).

In accordance with the data of the IV quarter of 2017, the microfinance organizations in Georgia have lend 1,137 bn. GEL in total, which compiles of 794481 in quantity. It is mainly represented by three sectors: trade and services - 249 ml. GEL (21.9\% of portfolio); agriculture and forestry - 118 $\mathrm{ml}$. GEL (10.4\% of portfolio); consumer loans - $671 \mathrm{ml}$. GEL (59.0\% of portfolio). High share of consumer loans among the total number of loans is important. 
Due to the clients of the microfinance organizations are citizens with low-income and their social conditions do not provide capacity to be well-informed, therefore, bearing in mind such data, in accordance with the interests of clients, the law sets the terms of the loan issuance and the rights and liabilities of the borrower and the lender.

The share of the funds attracted from natural persons in the structure of liabilities of microfinance organizations declined on the basis of the significant increase in institutional funding for resident and non-resident in 2014-2017, and due to the targeted activities carried out by the National Bank with regards to the retail investors. Microfinance organizations that attracted resources from less-informed retail investors were required to submit an action plan that would reduce the amount of funds attracted from individuals and implied the gradual exit from the retail segment. According to the plan, those microfinance organizations halted the advertising campaigns that attracted funds from natural persons and began replacing the retail creditors with qualified investors, which continued in 2017. The issue was particularly relevant, since the interest rates on the foreign currency dominated bank deposits have significantly decreased, which increased risks of flowing resourcing into non-banking channels. As a result of the measures taken, the structure of the creditor natural persons was somewhat improved.

Due to non-compliance of the instructions of the National Bank, 3 companies have been recognized as qualified credit institutions, which have been banned by the National Bank from attracting funds and conducting all kinds of advertising campaigns related to this activity and prohibiting delivering any kind of services in connection to the company related parties.

It is important that in order to reduce possible risks associated with management of the savings, on January 15, 2017, the amendment was added to the Civil Code of Georgia, according to which an entrepreneur or a group of interconnected entrepreneurs are restricted from attracting funds, if more than twenty individuals are attracted and each contribution is amounted to less than $100000 \mathrm{GEL}$. At the same time, the National Bank continues to work on the legislative framework aimed at improving the regulatory legislative base in terms of the accountability of the microfinance organizations and their interests of their customers.

For more details on the loans issued by microfinance organizations of Georgia in the II and IV quarters of 2018, refer to the table. (National Bank of Georgia, 2019)

As we can see, the financial companies have hold important position in the Georgian financial industry, and for this reason, their regulation is an essential issue, which should continue at least in the same manner. It is problematic that currently many financial companies, pawnshops, internetlenders or private people that are left beyond regulations. There is no guarantee the customers rights will be protected when the work of the financial intermediaries are not regulated. Such circumstances create a threat to the spread of predatory lending practices in the market, of which an unaware customer becomes the victim. It is noteworthy that a significant number of consumers, media and decision-makers in Georgia do not distinguish microfinance organizations from other non-bank credit organizations.

The impact of the COVID-19 pandemic has significantly reduced economic activity and increased financial stability risks worldwide. National Bank of Georgia for COVID-19 pandemic has taken significant steps to mitigate the negative impact on the countrys financial sector and stimulate the countryss economy.

Extraordinary steps have been taken in various directions and its including important ones - uninterrupted supply of liquid cash resources to various sectors of the economy, development of a temporary supervisory plan, expansion of the International Monetary Fund (IMF) program and launch of a new foreign exchange intervention mechanism.

The financial sector in Georgia is prepared for new challenges and despite the current situation, financial organizations continue to work: the financial sector continues to provide a full range of services without any delays. However, to avoid problems, there are some guidelines for the population - to make the most of Internet payment services. Banks and microfinance organizations in service centers avoid direct physical contact between service personnel and customers. Despite the pandemic, there is still

Table. Loans issued by microfinance organizations of Georgia in the II and IV quarters, 2018

\begin{tabular}{|c|c|c|c|c|c|}
\hline & & Total II & quarter 2018 & Total IV & quarter 2018 \\
\hline № & Name & Sum (GEL) & Amount of credits & Sum (GEL) & Amount of credits \\
\hline 1. & Loans granted to individuals & 1259444025 & 1003449 & 1080308722 & 785239 \\
\hline 1.1. & Trade and Services & 219189009 & 43680 & 187172434 & 37278 \\
\hline 1.2 . & Consumer Loans & 367283802 & 141763 & 337116397 & 101243 \\
\hline 1.3 . & Agriculture & 108446905 & 21902 & 94893580 & 18507 \\
\hline 1.4. & Online Loans & 185937377 & 388770 & 105282450 & 215788 \\
\hline 1.5. & Collateral Credits & 320912728 & 358620 & 299862866 & 346702 \\
\hline 1.6. & Installments & 20989707 & 45798 & 32210326 & 61018 \\
\hline 1.7. & Other & 36684496 & 2916 & 23770669 & 4703 \\
\hline 2. & Loans granted to Legal entities & 18247324 & 791 & 21222653 & 878 \\
\hline 3. & Total Loans & 1277691349 & 1004240 & 1101531374 & 786117 \\
\hline
\end{tabular}


an active demand from the population for the products of microfinance organizations.

In conclusion, microfinance organizations have a big role in the Georgian financial system and as for the non-banking financial sector of Georgia. This area has the potential to promote serious growth and financial enhancement. Financial enhancement means the development of diverse financial instruments and improving capital distribution, financial intermediation quality and efficiency of the overall financial system. All these will make the capital more accessible to the people, which, ultimately, will contribute to the growth of the countrys economy.

\section{REFERENCES}

Lee, S. (2017), Introduction to Microfinance Institutions (MFIs), Part I. Medium Calvert Impact Capital, Inc., available at: https://www.calvertimpactcapital.org/blog/683-intro-to-mfis (Accessed 22.02.2019).

Members of the Georgian Microfinance Association, available at: www.microfinance.ge/members-of-association/ (Accessed 02.03.2019)

Mosiashvili, V., Chelidze, M. and Khidirbegishvili, N. (2017), Financial Institutions and Markets. Dani, Tbilisi, 461

National Bank of Georgia, List and coordinates of non-banking institutions registered in Georgia, available at: www.nbg.gov. ge/index.php?m=529 (Accessed 03.03.2019)

National Bank of Georgia, Summary financial indicators of non-banking institutions in Georgia, available at: www.nbg.gov.ge/ index.php? $\mathrm{m}=703$ (Accessed 05.03.2019)

Parliament of Georgia (2006), Law of Georgia „On the Microfinance Organizations“, Tbilisi.

Parliament of Georgia (2009), Organic Law of Georgia „On the National Bank of Georgia“, Tbilisi.

Guntz, S. (2011), Sustainability and profitability of microfinance institutions. University of Applied Sciences Nuremberg. Research Paper 4/2011.

The Georgian Microfinance Association, Activities, available at: www.microfinance.ge/activities/ (Accessed 28.02.2019) The

Georgian Microfinance Association (2009), Charter, available at: www.microfinance.ge/wp-content/uploads/\%E1\%83\%A C\%E1\%83\%94\%E1\%83\%A1\%E1\%83\%93\%E1\%83\%94\%E1\%83\%91\%E1\%83\%902.pdf (Accessed 01.03.2019)

The National Bank of Georgia (2012), Order, On approval of the rules and conditions for registration of the microfinance organization in the National Bank of Georgia, N33/04, Tbilisi.

UFA2020 Overview: Universal Financial Access by 2020 (2018), available at: https://www.worldbank.org/en/topic/ financialinclusion/brief/achieving-universal-financial-access-by-2020 (Accessed 02.03.2019) 